\title{
SIMULATION PARAMETERS OF FRICTION AND WEAR CONJUGATION IN THE FRICTION CYLINDER
}

\author{
А.Ю. Шабанов, А.Б. ЗайщеВ, А.А. Метелев, Ю.П. Пустовалов \\ МОДЕЛИРОВАНИЕ ПАРАМЕТРОВ ТРЕНИЯ И ИЗНОСА \\ СОПРЯЖЕНИЙ ТРЕНИЯ ЦПГ ПОРШНЕВОГО ДВИГАТЕЛЯ
}

\begin{abstract}
The article presents the results of research which aims to develop a model of the friction units of the cylinder-piston group, i.e., the "piston ring - cylinder liner" and "piston trunk - cylinder liner" couples taking into account the change in the real state of the working surfaces of the mating parts and lubricating oil. We have examined the factors that have a progressive impact on the operation of the engine friction units during their wear life. The impact of these factors on the wear and forecasting it has been assessed. We propose the method for predicting the operation life and the real state of the engine. An experimental study to validate the developed method to the particular engine has been conducted.
\end{abstract}

WEAR; INTERNAL COMBUSTION ENGINE; LIFE PREDICTION; ENGINE OIL; TRIBOUNIT.

В статье представлены результаты научно-исследовательской работы, цель которой - разработать модель узлов трения цилиндропоршневой группы, а именно пар «поршневое кольцо - втулка цилиндра» и «тронк поршня - втулка цилиндра». Модель учитывает изменение реального состояния рабочих поверхностей сопрягаемых деталей (тронк поршня, первое и второе поршневое кольцо, маслосъемное кольцо, зеркало цилиндра, коренные и шатунные шейки и вкладыши коленчатого вала) и смазочного масла. Рассматриваются факторы, оказывающие прогрессирующее влияние на работу узлов трения двигателя по мере их износа. Оценена степень влияния этих факторов на износ и его прогнозирование. Предложен метод для прогнозирования ресурса и реального состояния двигателя. Проведено экспериментальное исследование для подтверждения правильности разработанной методики на конкретном двигателе.

ИЗНОС; ДВИГАТЕЛЬ ВНУТРЕННЕГО СГОРАНИЯ; ПРОГНОЗИРОВАНИЕ РЕСУРСА; МОТОРНОЕ МАСЛО; ТРИБОСОПРЯЖЕНИЯ.

\section{Introduction}

Change of technical and economic parameters of the engine during the service life (from the beginning of operation to write-off) in many respects is defined by dependence on real condition of its friction units, first of all - the cylinder-piston group (CPG). However the existing models describing the frictional processes in an internal combustion engine (ICE) do not consider the change dynamics of the key design data during the deterioration of the friction couples.

Research objective is to propose the model of work of the cylinder-piston group friction units (couples «piston ring-cylinder liner» and «piston trunk-cylinder liner») considering change of real condition of the working surfaces of mating parts and lubricating oil.
Method of achieving this goal. We will emphasize the following from the factors having essential impact on work of CPG friction units and changing itselfduring operation:

1) change the gap values in CPG friction mating caused by processes of wear of cylinder liner working surfaces, pistons, and piston rings. As practice shows, the basic wear is occurred in the forming cylinder liner leading to formation the difficult conical and oval profile of its working surface. Tracking of this profile with elastic piston rings leads to continuous change of expansion gap values in the piston ring joints, and the average values of the gaps tends to increase in the process of wear. Losses of working medium in the combustion chamber are defined generally by leakages throughthe ring expansion gaps $[1,2]$ therefore 
the current state of the forming cylinder liner significantly influences on the course of the indicator process in the engine cylinders and on the piston ring gas loads. The mechanism of rising force formation in the gaps under the rings and the piston allows us to neglect the cylinder working surface deplanation caused by wear and thereby not to consider this factor at the change of the form of the gaps and impinging angles of the flat bearing formed in these couplings. At the same time it is necessary to consider the change of the form forthe friction surfaces of the piston rings and piston trunk caused by wear;

2) change the current state of the working surfaces of the CPG parts caused by accumulation the friction defects on them in use. In spite of this factor is especially casual, it has essential impact on work of the CPG flat bearings, changing the value and nature of distribution in them the rising force hydrodynamic pressure;

3 ) change the physical and chemical parameters of lubricating oil in the course of its long work, first of all the change of kinematic viscosity and the composition of the antiwear additives complex influencing friction coefficients in the couplings at disturbances of the friction hydrodynamic regime.

The first two factors are constant operating ones; their influence gradually increases in the process of the engine operating time during the period from the beginning of operation (the end of the break-in period) till capital repairs when there is a restoration of the friction units. The third factor is cyclic, acting between maintenance of the engine with change of engine oil.

As a result of the complex of theoretical and experimental studies conducted by the authors for the last years the approaches allowing to enter into classical model the description of the frictional processes in ICE CPG $[1,3,4]$ the majority of the above influence factors of engine current state on the indicators of friction and wear have been formulated.

The factor of change the gaps in CPG friction mating is considered as follows.

Taking into account the leakage values of working medium from the combustion chamber on the indicator process in ICE cylinders is realized by the joint solution of the equations of the first law of thermodynamics for the combustion chamber and beyond ring volumes formed by lateral surfaces of the piston rings and the piston with cylinder walls $[6,7]$.

\section{Calculated and Experimental Assessment}

The system of the differential equations describing the mentioned thermodynamic process has the following appearance:

$$
\partial Q_{T}-\partial Q_{W}=\partial U+\partial A+\sum i_{k} \partial M_{k}+i_{p r} \partial M_{p r} .
$$

Where $\partial \mathrm{T}=\mathrm{g}_{\mathrm{C}} \mathrm{Q}_{\mathrm{T}} \partial \mathrm{x}-$ heat released during combustion of fuel; $\mathrm{g}_{\mathrm{c}}$ - cyclic fuel feed, $\mathrm{kg} /$ cycle; $\mathrm{Q}_{\mathrm{T}}-$ fuel net calorific value, $\mathrm{J} / \mathrm{kg} ; x-$ relative heat; $\partial Q_{\mathrm{w}}=\alpha_{G} F_{W}\left(T-T_{W}\right) d t-$ heat loss due to heat exchange with the combustion chamber walls; $\alpha_{G}-$ medium over the surface instantaneous heat transfer coefficient from working medium, W/m $\cdot \mathrm{K} ; F_{W}$ - heat exchange surface area; $T, T_{W}$ - temperatures of working medium and the combustion chamber surface, respectively, $K ; \partial U=\partial\left(M C_{V} T\right) d t-$ change in internal energy of the thermodynamic system; $M$ - mass, $C_{V}$ - isochoric heat capacity of working medium; $\partial \mathrm{A}=\Pi \partial V$ - work instantaneous value; $P$ - working medium pressure, $\partial V$ - cylinder volume change; $i_{k}$, $\partial M_{k}-$ respectively enthalpies and working medium mass flows through the valvesand piston ring joints of CPG; $i_{p r}, \partial M_{p r}$ - respectively enthalpies and working medium mass flows through gappings of the first piston ring tothecylinder liner surface.

The masses of leakages of working medium from the combustion chamber in the engine case depend on piston rings set gas tightness, and consequently, on degree of the cylinder wear [8-10]. The real condition of the cylinder liner is considered by use in the calculation the profile ofthe deformed and worn out cylinder generatric, gained by direct measurement, or by modeling of cylinder wear, for example by means of the technique [6]. Taking into account the local deformation and wear of the cylinder liner the current gap in the piston ring joint changes:

$$
\Delta_{k}(z)=\Delta_{k o}\left(T_{k}\right)+2 \pi \Delta\left(z, T_{G}\right),
$$

where $\Delta_{k}(z)$ - current gap in the piston ring joint; $\Delta_{k 0}\left(T_{k}\right)$ - expansion gapin the jointat the ring temperature $T_{k} ; \Delta\left(z, T_{G}\right)$ - cylinder generatric radial deformationat the operating temperatureof the sleeve $T_{G}$ taking into account its wear.

Figure 1 shows the results of gas load modeling at the first and second ring of the piston for the forced diesel at different degrees of the engine wear. These 
results indicate that in the process of wear because of increase the leakages from the combustion chamber the gas load of the first piston ring decreases, but of the second one - increases. Influence of growth of leakages on the indicator showings of the engine in general is insignificant and is shown generally in a zone of small rotation frequencies of the crank shaft. Such redistribution of the gas load influences the power of friction losses and extent of wear zones.

Taking note of the real condition of the friction surfaces on formation of the bearing ability of the piston rings and piston trunks is carried out in the following way: the parameter which is conditionally called the "damage surface factor" is entered into the mathematical model for calculation the thickness of a lubricant layer in these couplings. It is calculated on the following dependence:

$$
\Omega=P_{r f \text { real }} / P_{r f \text { id }},
$$

where $P_{\text {rf real }}-$ pressure of the hydrodynamic rising force for the real worn bearing, having certain amount of friction defects; $P_{\text {rf id }}-$ pressure of the hydrodynamic rising force for the bearing with an ideal surface on the same design conditions.

To determine the values of damage surface factor there was the special calculated experiment at which the numerical modeling of the hydrodynamic processes in the flat bearing with different types, sizes and amount of conditional friction defects in comparison to the ideal bearing under identical conditions of loading was carried out. In figures 2 and 3 the typical pictures of distribution of the hydrodynamic pressure in the bearings having a certain amount of friction defects are presented.

Taking into account this refinement, the final systems of the differential equations for the description the processes of formation of the hydrodynamic lubricant layers look as follows:

for the piston rings

$$
\begin{gathered}
\partial C_{k} / \partial \varphi=\pi D h\left[\left(P_{i}-P_{i-1}\right) / 2-P_{y}-\right. \\
\left.-1,01 \mu(M) \Omega_{i} h_{i}^{2}\left(C_{k}-C_{p}\left(\alpha_{i}+\delta / 2 h_{i}\right)\right) / \delta^{3}\right] / 6 n m_{k} \\
\partial C_{k} / \partial \varphi=C_{k} / 6 n
\end{gathered}
$$

where $C_{\kappa}$ - radial movement speed of the piston ring; $\alpha_{i}, h_{i}$ - parameters describing the working profile of the piston ring; $m_{k}-$ ring mass; $\mu(M)-$ medium viscosity where tghe piston ring works; $\Omega_{i}$ - damage surface factor, considering existence on a working surface of the friction couple the defects caused by wear process; it is defined on the basis of the analysis of a profilogram of the worn-out rin;

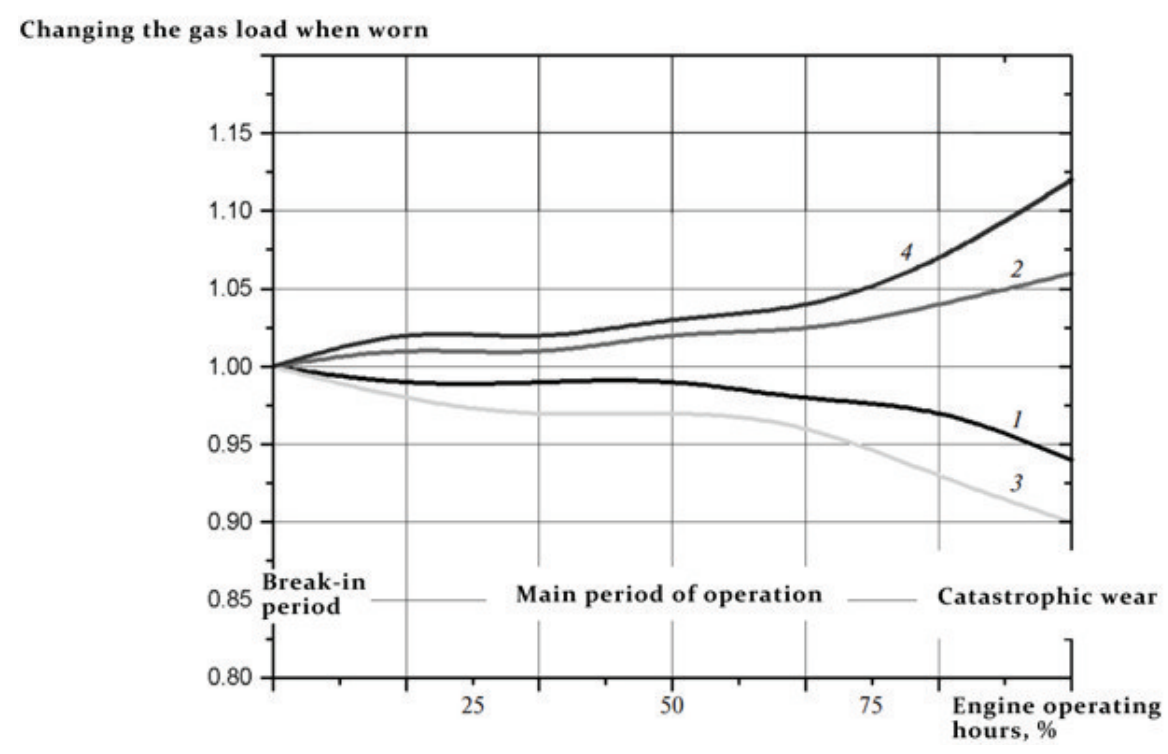

Fig. 1. The relative change in gas loadat the first and second piston ring of the forceddieselvarious modes of operation depending on the engine wear factor

(relative to the initial state): 1 - first ring,crank shaft high speed mode;

2 - second ring,crank shaft high speed mode; 3 - first ring, crank shaft low speed mode; 4 - second ring, crank shaft low speed mode 


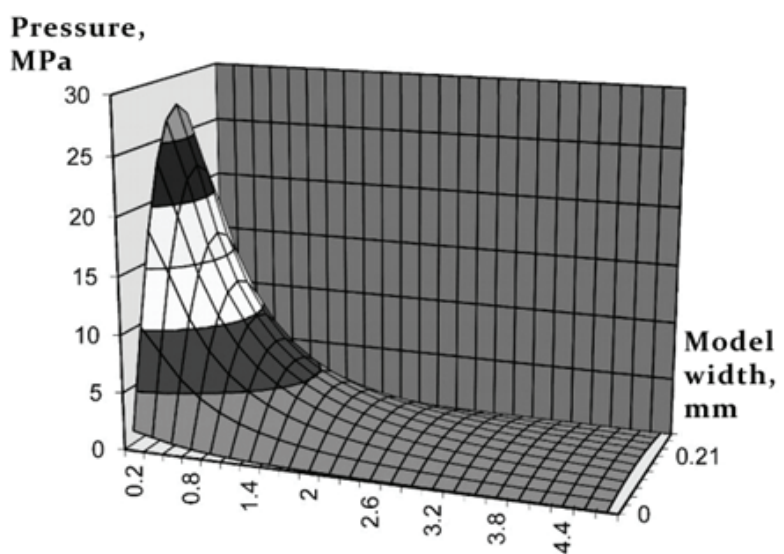

Fig. 2. Diagram of the hydrodynamic pressure in the ideal bearing

for the oil scraper ring this system of equations can be written as

$$
\begin{gathered}
\partial C_{k} / \partial \varphi=\pi D h_{i c}\left[\rho_{\mathrm{M}} C_{P}^{2} / \pi^{2}-P_{y}-\right. \\
-1,01 \mu \Omega_{i} h_{i c}^{2}\left(C_{K}-C_{p}\left(\delta / 2 h_{i c}\right)\right) / \delta^{3} / 6 n m_{k} ; \\
\partial \delta / \partial \varphi=C_{k} / 6 n,
\end{gathered}
$$

where $\rho_{\mathrm{M}}-$ oil density; $h_{i c}-$ height of the scrapers work surfaces for the oil scraper ring;

for the piston trunk

$$
\left\{\begin{array}{l}
m_{P} \frac{d c_{r}}{d \varphi}=\frac{1}{6 n}\left(\Omega P_{G D}-P_{N}\right) ; \\
J_{P} \frac{d \omega_{P}}{d \varphi}=\frac{1}{6 n}\left(\Omega M_{G D}-M_{N}\right) \\
\frac{d \delta_{\min }}{d \varphi}=\frac{c_{r}}{6 n} ; \\
\frac{d \alpha}{d \varphi}=\frac{\omega_{P}}{6 n},
\end{array}\right.
$$

where $P_{N}-$ normal force acting on the piston; $M_{N}$ - longitudinal force moment relative to the piston pin axis; $P_{G D}-$ hydrodynamic force acting on the piston,

$$
\begin{aligned}
& P_{G D}=6 \mu c_{P} \int_{0}^{x} d x \int_{0}^{x} \frac{d t}{\left(\delta_{0}+\delta^{*}\right)}+12 \mu \frac{d \delta}{d t} \int_{0}^{L} d x \int_{0}^{x} \frac{t d t}{\left(\gamma_{0}+\delta^{*}\right)^{3}}- \\
& -6 \mu c_{P} \Delta \varphi\left(1+\frac{12 B(\varphi) n \frac{d \delta}{d t}}{A(\varphi) c_{P}}\right) \int_{0}^{x} d x \int_{0}^{x} \frac{d t}{\left(\delta_{0}+\delta^{*}\right)^{3}}
\end{aligned}
$$

$$
A(\varphi)=\int_{0}^{L} \frac{d x}{\delta^{2}} / \int_{0}^{L} \frac{d x}{\delta^{3}} ; \quad B(\varphi)=\int_{0}^{L} \frac{x d x}{\delta^{3}} / \frac{d x}{\delta^{3}} ;
$$

$\mu$ - dynamic oil viscosity; $L-$ trunk length; $M_{G D}$ - hydrodynamic force moment, acting on the piston relative to the piston pin axis,

$$
M_{G D}=\int_{L_{1}}^{L_{2}} x d x \int_{-90}^{90} P(x, \varphi, \theta) \cos \theta d \theta
$$

$m_{p}-$ piston mass; $J_{p}-$ piston moment of inertia relative to the rotational axis (piston pin); $c_{r}$ - radial movement speed of the piston forming an oil layer; $\omega_{P}-$ angular speed of the piston; $\varphi-$ crank rotation angle; $n$ - engine rotation speed; $\delta_{\min }-$ minimum gap in front of the trunk; $\alpha-$ angle of obliquity of the piston axis relative to the cylinder axis.

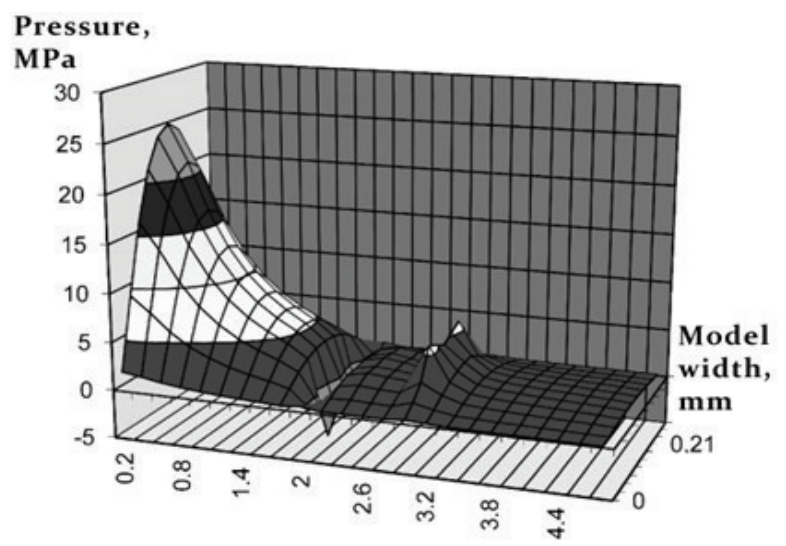

Fig. 3. Diagram of the hydrodynamic pressure in the ideal bearing with two friction defects

Figure 4 shows the calculation results of the relative change for lengths of the friction tracks (wear zones) on the walls of the cylinder liners of the forced diesel at different stages of its wear. Figure 5 shows thecalculation results of power of mechanical losses in CPG for the same diesel during its work on the external speed characteristic at the same stages of wear.

\section{Results of the Computational and Experimental Studies}

The modeling results show that at small and average stages of wear the power of the mechanical losses in a set of the piston rings becomes slightly less than calculated power for the initial condition of the engine. The factor of some decrease in the gas load level of the first piston ring affects with a growth of 
gaps, thus the damage factor value is still rather small and poorly influences the lubricant layer thickness. With a growth of the surface damage degree that is characteristic at high degrees of the engine wear, there is a noticeable falling of the oil layer bearing ability value leading to increase the boundary friction zone. At the same time the power of mechanical losses grows; and this factor starts influencing much more, than the gas loading change of the rings caused by the progressing wear.

Changing the gas load when worn

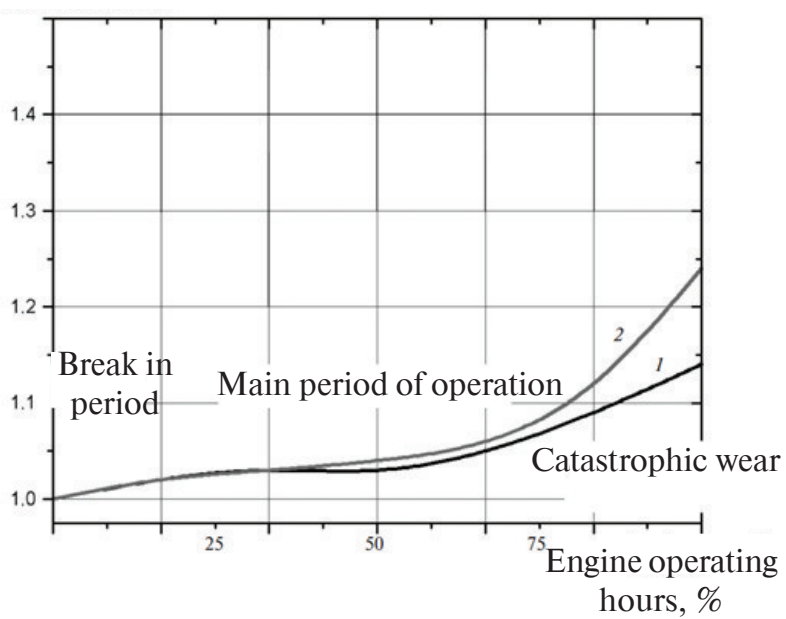

Fig. 4. Relative change of the lengths of the friction tracks on theworking surface of the cylinder liners for theforced diesel atvarious modes of operation depending on the engine wear factor (relative to the initial state): 1 - crank shaft high speed mode; 2 - crank shaft low speed mode

Friction power in $\mathrm{CPG}, \mathrm{kW}$

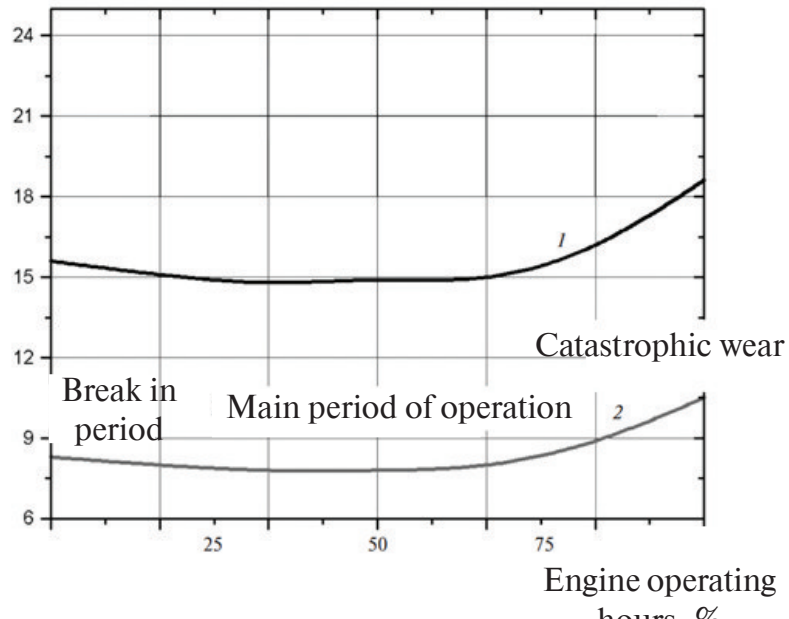
hours, $\%$

Fig. 5. Changing the friction powerin theforced dieselCPG for various modes of operation depending on the engine wear factor: 1 - crank shaft high speed mode; 2 - crank shaft low speed mode
Oil kinematic viscosity, cSt

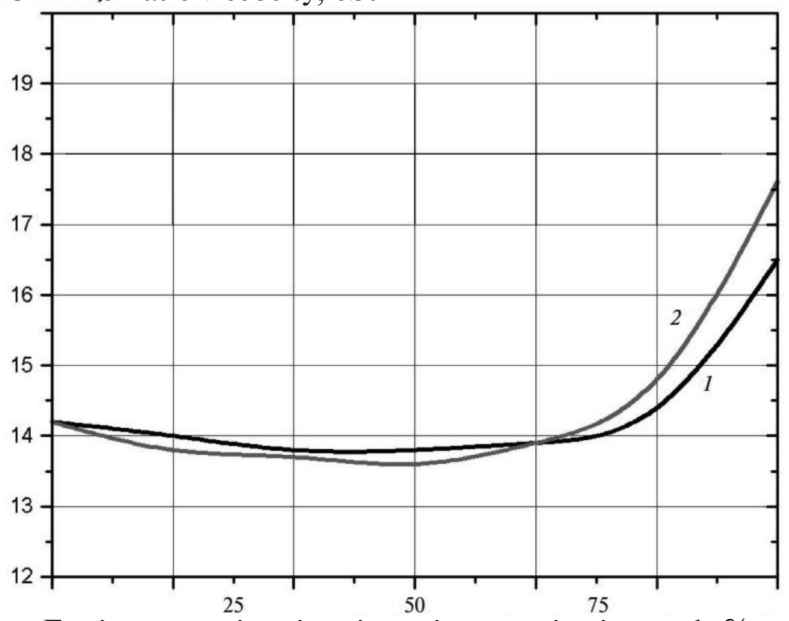

Engine operating time in an interservice interval, \%

Fig. 6. Change the engine oil kinematic viscosity at different periods of its use: 1 - at the modes withcrank shaft high speed;2 - at the modes withcrank shaft low speed

The factor of change of the physical and chemical parameters of the lubricating oil depending on lubrication operating time degree in the engine in an interserviceinterval is considered by use the dependence of the engine oil kinematic viscosity. It is calculated with the help of the Walter unified dependence [5]:

$$
\begin{aligned}
& \lg \lg (n)=A(\tau)+B(\tau) t+C(\tau) t^{2} ; \\
& \lg \lg \left(v_{t}\right)=A(\tau)+B(\tau) t+C(\tau) t^{2},
\end{aligned}
$$

where $v_{t}$ - desired value of the kinematic viscosity at the temperature $t, \mathrm{cSt} ; t$ - temperature, ${ }^{\circ} \mathrm{C} ; \mathrm{A}(\tau), \mathrm{B}(\tau)$, $\mathrm{C}(\tau)$ - approximation coefficients taking into account oil operating time in an interservice intervalt.

Approximation coefficients of theoil viscosity change were determined for big sample group of marketable oils by the long resource tests according tothe technique of the SPBPU DAiGM chair. Typical curve of viscosity changesfor lubricating oil in the period of an interservice interval are shown in fig. 6 .

\section{Conclusion}

Numerous calculated researches the work of the CPG friction units in the piston ICEs show that all three factors progressing in the process of engine wear have approximately equivalent impact on the engine outcome indicators and therefore have to be considered in forecasting of the ICE resource indicators. The offered technique realizes rather effective tool for solving this problem. 


\section{REFERENCES}

1. Petrichenko R. M., Baturin S.A., Isakov Yu.N. [i dr]. Elementy sistemy avtomatizirovannogo proyektirovaniya DVS: Algoritmy prikladnykh programm / Pod obshch. red. R.M. Petrichenko. L.: Mashinostroyeniye, 1990. 328 s. (rus.)

2. Petrichenko R.M. Fizicheskiye osnovy vnutritsilindrovykh protsessov $\mathrm{v}$ dvigatelyakh vnutrennego sgoraniya. L.: Izd.-vo Leningr. un-ta, 1983. 244 s. (rus.)

3. Petrichenko R.M., Shabanov A.Yu. [i dr]. Treniye i teploobmen v porshnevykh koltsakh DVS. L.: Izd.-vo LGU, 1990. 320 s. (rus.)

4. Shabanov A.Yu., Zaytsev A.B., Ryzhenkov Yu.V. Vliyaniye sostoyaniya poverkhnostey treniya dvigatelya vnutrennego sgoraniya na iznos detaley i kharakteristiki yego raboty. Nauchno-tekhnicheskiye vedomosti SPbGPU. Osnovnoy vypusk. 2008. № 2(54). S. 199-202.

5. Shabanov A.Yu., Zaytsev A.B., Kudinov I.S. O novykh metodakh approksimatsii vysokotemperaturnoy kinematicheskoy vyazkosti motornykh masel. Nauchnyye issledovaniya i innovatsionnaya deyatelnost: Materialy nauch.-prakt. konf. SPb.: Izd-vo Politekhn. un-ta, 2011. - S. 42-50. (rus.)
6. Galyshev Yu.V., Shabanov A.Yu., Zaytsev A.B., Metelev A. A. Metodika uskorennykh ispytaniy motornykh masel na izmeneniye ikh svoystv v techeniye sroka ekspluatatsii. Nauchno-tekhnicheskiye vedomosti SPBGPU. 2012. № 1(147). S. 71-76. (rus.)

7. Shabanov A.Yu., Zaytsev A.B., Kudinov I.S., Metelev A.A., Vliyaniye nekotorykh fiziko-khimicheskikh pokazateley motornogo masla na tekhniko-ekonomicheskiye i resursnyye pokazateli porshnevykh benzinovykh dvigateley. Dvigatelestroyeniye. 2011. № 1. S. 24-28. (rus.)

8. Kolchin A.I., Demidov V.P. Raschet avtomobilnykh i traktornykh dvigateley: Ucheb. Posobiye dlya vuzov. 3-ye izd. pererab. i dop. M.: Vyssh. shk., 2002. 496 s. (rus.)

9. Dyachenko N.Kh., Kharitonov B.A., Petrov V.M. [i dr]. Konstruirovaniye i raschet dvigateley vnutrennego sgoraniya / Pod red. N.Kh. Dyachenko. L.: Mashinostroyeniye. 1979. 392 s. (rus.)

10. Vasilyev B. N. Zavisimost soprotivleniya treniya porshnevykh kolets ot davleniya na ikh rabochuyu poverkhnost. Izvestiya vuzov. Mashinostroyeniye. 1967. № 7. S. 15-18. (rus.)

\section{СПИСОК ЛИТЕРАТУРЫ}

1. Петриченко Р.М. , Батурин С.А., Исаков Ю.Н. [и др]. Элементы системы автоматизированного проектирования ДВС: Алгоритмы прикладных программ. / Под общ. ред. Р.М. Петриченко. Л.: Машиностроение, 1990. 328 с.

2. Петриченко Р.М. Физические основы внутрицилиндровых процессов в двигателях внутреннего сгорания. Л.: Изд-во Ленингр. ун-та, 1983. 244 с.

3. Петриченко Р. М., Шабанов А. Ю. [и др]. Трение и теплообмен в поршневых кольцах ДВС. Л.: Изд-во ЛГУ, 1990. 320 с.

4. Шабанов А.Ю., Зайцев А.Б., Рыженков Ю.В. Влияние состояния поверхностей трения двигателя внутреннего сгорания на износ деталей и характеристики его работы // Научно-технические ведомости СПбГПУ. Основной выпуск. 2008. № 2 (54). C. 199-202.

5. Шабанов А.Ю., Зайцев А.Б., Кудинов И.С. О новых методах аппроксимации высокотемпературной кинематической вязкости моторных масел // Научные исследования и инновационная деятельность: Материалы науч.-практ. конф. СПб.: Изд-во Политехн. ун-та, 2011. С. 42-50.
6. Галышев Ю.В., Шабанов А.Ю., Зайщев А.Б., Метелев А.А. Методика ускоренных испытаний моторных масел на изменение их свойств в течение срока эксплуатации // Научно-технические ведомости СПБГПУ. 2012. № 1(147). С. 71-76.

7. Шабанов А.Ю., Зайщев А.Б., Кудинов И.С., Метелев А.А. Влияние некоторых физико-химических показателей моторного масла на технико-экономические и ресурсные показатели поршневых бензиновых двигателей // Двигателестроение. 2011. № 1. С. 24-28.

8. Колчин А.И., Демидов В.П. Расчет автомобильных и тракторных двигателей: Учеб. Пособие для вузов. 3-е изд. перераб. и доп. М.: Высш. шк., 2002. $496 \mathrm{c}$.

9. Дьяченко Н.Х., Харитонов Б.А, Петров В.М. [и др]. Конструирование и расчет двигателей внутреннего сгорания / Под ред. Н.Х. Дьяченко. Л.: Машиностроение, 1979. 392 с.

10. Васильев Б. Н. Зависимость сопротивления трения поршневых колец от давления на их рабочую поверхность // Известия вузов. Машиностроение. 1967. № 7. C. $15-18$. 


\section{СВЕДЕНИЯ ОБ АВТОРАX/AUTHORS}

SHABANOV Aleksandr Yu. - Peter the Great St. Petersburg Polytechnic University.

29 Politechnicheskaya St., St. Petersburg, 195251, Russia.

E-mail: aush2003@mail.ru

ШАБАНОВ Александр Юрьевич - кандидат технических наук профессор Санкт-Петербургского политехнического университета Петра Великого.

195251, Россия, г. Санкт-Петербург, Политехническая ул., 29.

E-mail: aush2003@mail.ru

ZAITSEV Aleksei B. - Peter the Great St. Petersburg Polytechnic University.

29 Politechnicheskaya St., St. Petersburg, 195251, Russia.

E-mail: abzaytsev@mail.ru

ЗАЙЦЕВ Алексей Борисович - кандидат технических наук доцент Санкт-Петербургского политехнического университета Петра Великого.

195251, Россия, г. Санкт-Петербург, Политехническая ул., 29.

E-mail: abzaytsev@mail.ru

METELEV Andrei A. - Peter the Great St. Petersburg Polytechnic University.

29 Politechnicheskaya St., St. Petersburg, 195251, Russia.

E-mail: petmet@mail.ru

МЕТЕЛЕВ Андрей Александрович - аспирант Санкт-Петербургского политехнического университета Петра Великого.

195251, Россия, г. Санкт-Петербург, Политехническая ул., 29.

E-mail: petmet@mail.ru

PYSTOVALOV Yurii P. - Peter the Great St. Petersburg Polytechnic University.

29 Politechnicheskaya St., St. Petersburg, 195251, Russia.

E-mail: yurapust@mail.ru

ПУСТОВАЛОВ Юрий Петрович - аспирант Санкт-Петербургского политехнического университета Петра Великого.

195251, Россия, г. Санкт-Петербург, Политехническая ул., 29.

E-mail: yurapust@mail.ru 